\title{
Immature Development of Spodoptera dolichos (Fabricius) (Lepidoptera: Noctuidae)
}

\author{
DG Montezano ${ }^{1}$, DR Sosa-Gómez ${ }^{2}$, SV Paula-Moraes ${ }^{3}$, VF Roque-Specht ${ }^{4}$, E Fronza ${ }^{1}$, NM Barros ${ }^{1}$, \\ A SPECHT ${ }^{3}$
}

${ }^{1}$ Instituto de Biotecnologia, Univ de Caxias do Sul, Caxias do Sul, RS, Brasil

${ }^{2}$ Embrapa Soja, Londrina, PR, Brasil

${ }^{3}$ Embrapa Cerrados, Planaltina, DF, Brasil

${ }^{4}$ Fac UnB Planaltina, Univ de Brasília, Planaltina, DF, Brasil

\section{Keywords}

Armyworm, artificial diet, crop pests, sweet potato armyworm

\section{Correspondence}

A Specht, Lab de Entomologia, Embrapa Cerrados, Rodovia BR-020, Km 18 Caixa, Postal 08223, 73310-970 Planaltina, DF, Brasil; alexandre.specht@embrapa.br

Edited by Regiane C Freitas Bueno - UNESP

Received 30 October 2014 and accepted 3 September 2015

Published online: 1 October 2015

(C) Sociedade Entomológica do Brasil 2015

\section{Introduction}

The genus Spodoptera Guenée (Lepidoptera: Noctuidae) comprises one of the most important pest groups worldwide (Pogue 2002). The species Spodoptera dolichos (Fabricius) is reported from North to South America (e.g., Silva et al 1968, Ferguson et al 1991, Pogue 2002, Pastrana 2004), with adults being captured in light traps throughout the year (e.g., Specht \& Corseuil 2002, Zagatti et al 2006, Zenker et al 2010). Chile is the only South American country that has not reported the presence of $S$. dolichos (Angulo et al 2008).

The economic importance of $S$. dolichos is widely reported in the literature (Crumb 1929, Silva et al 1968, Pastrana 2004). Several crops are reported as hosts of S. dolichos, such as asparagus, bean, brinjal, cabbage, cassava, coffee, corn, cotton, ground pea, onion, potato, strawberry, sweet potato, tobacco, tomato, and watermelon (e.g., Silva et al 1968, Pogue 2002, Pastrana 2004). Moreira (1929) described
S. dolichos as a pest causing significant economic damage in vegetables. The injury caused by $S$. dolichos larvae in many hosts is defoliation (Teixeira \& Yokomizo 1987, Dias et al 2009), but feeding on fruits of watermelon (Adlerz 1975), stigmas of corn (Matrangolo et al 1997), and cutting young plants at the soil surface (Crumb 1929, Moreira 1929) are also reported.

The biology of $S$. dolichos is poorly characterized. One of the possible reasons is the similarity with other species from the Spodoptera genus, such as Spodoptera albula (Walker) and Spodoptera eridania (Stoll), which has caused frequent misidentification (Pogue 2002). In the present study, the immatures of $S$. dolichos are described using neonates evaluated individually until adult emergence. The investigation of the biological parameters of male and female immatures was performed by preserving the identity of each larva throughout the study with minimal interference in development. The rearing conditions and artificial diet were the same used in studies with $S$. albula 
and S. eridania in order to allow interspecific biology comparison among the three species.

\section{Material and Methods}

\section{Insects and laboratory conditions}

Four females and five males were collected from light traps in the municipality of Pinto Bandeira, state of Rio Grande do Sul, Brazil (29 $02^{\prime} 50^{\prime \prime} \mathrm{S}, 5^{\circ} 28^{\prime} 12^{\prime \prime} \mathrm{W}$; $613 \mathrm{~m}$ a.s. I). Identification was conducted by comparing adults including genitalia with descriptions in Pogue (2002). Adults of $S$. dolichos were placed in oviposition cages and 1-day-old egg masses were collected. Egg, larval, and pupal development were then evaluated. All the experiments were performed in a rearing room $\left(25 \pm 1^{\circ} \mathrm{C}\right.$, $70 \pm 10 \% \mathrm{RH}$, and a $14 \mathrm{~h}$ photophase), and the evaluations were performed daily at 2:00 p.m.

\section{Egg stage}

The viability and embryonic period were evaluated for 6485 eggs (from 53 egg masses). The egg masses were obtained from 12 oviposition cages with one couple each. The egg masses selected were representative of the oviposition period (including the first and last oviposition). Copulation was confirmed by counting the number of spermatophores in the bursa copulatrix, indicating that they had been inseminated during the experiment. The egg masses used were from females with one $(n=9)$ and two $(n=3)$ spermatophores. Every 1-day egg mass was individually placed into a Petri dish (10 cm diameter and $1.5 \mathrm{~cm}$ height) lined with filter paper moistened with distilled water until eclosion.

\section{Larval stage}

The larval development study was conducted using three hundred 1-day-old neonates. The artificial diet used to rear the larvae was adapted from Greene et al (1976) according to Montezano et al (2013a). The neonates were selected from the same female and were individually placed in plastic containers (300 $\mathrm{mL})$. A small wad of cotton ( $\sim \mathrm{cm}$ in diameter) moistened with distilled water to maintain humidity and a $\sim \mathrm{cm}^{3}$ piece of artificial diet were deposited in the plastic container. Daily observations were made to verify the survival and development of the larva by collection of shed head capsules. The head capsules were individually stored in tubes and measured under microscopy. In cases where the head capsule was not recovered due to larval consumption, changes of instar were noted by comparing its size with other larvae. The diet and the moist cotton were also replaced daily.

Head capsule measurement was based on the distance between the frontal setae of the head capsule because it is more precise than the traditional method that measures the distance between genas (Pérez et al 2005). The distance between the frontal setae was used to compare development of larvae that went through six and seven instars. The distance between genas was only measured in the first and in the last instar to allow data comparison with other species of Spodoptera.

When the larvae reached the prepupal period, characterized by a decrease in size and the interruption of feeding, the insect was transferred to another container (translucent plastic container, $10 \mathrm{~cm}$ diameter, $5 \mathrm{~cm}$ height) with expanded vermiculite moistened with distilled water. The prepupae built the pupal chamber attached to the wall of the container, which made it possible to observe pupation and metamorphosis.

Growth ratio was determined by measuring the frontal setae of each instar of 30 randomly sampled larvae (15 females and 15 males) that reached sixth instar. All larvae that reached seventh instar $(n=13)$ had their frontal setae measured for each instar (Table 3). The mean growth ratio was calculated by subtracting the mean of each instar by the predecessor.

\section{Pupal stage}

Pupae were kept in the same container and conditions as in the prepupal stage. The daily activities consisted of maintaining the moisture, with a few drops of distilled water, and recording the emergence of adults. Sex determination was performed on the second day after pupation when the cuticle was further hardened following Angulo \& Jana (1982). Mass was measured using a high-precision semi-analytical balance. Considering that precise sex determination is only possible during the pupal stage, the identity of each larva was preserved from throughout the study. Therefore, it was possible to track the development of each S. dolichos, including the gender.

The biological parameters such as duration, size, and weight were analyzed using descriptive statistics with the calculation of means and standard deviations. The sex ratio considers the number of females divided by the number of females and males. When necessary, means of sexes and larvae that underwent six or seven instars were compared using a $t$ test assuming unequal variances at a significance level of $5 \%$ and $1 \%$ using SPSS ${ }^{\circledR}$ (Statistical Package for the Social Sciences) version 11.0 for Windows.

\section{Results}

The overall survival of immature stages of $S$. dolichos was approximately $87 \%$ (Table 1), and embryonic development took 5 days (Table 1). Survival at the larval stage was 
Table 1 Survival and duration of the Spodoptera dolichos immature stages, on artificial diet, under controlled conditions $\left(25 \pm 1^{\circ} \mathrm{C}, 70 \pm 10 \%\right.$ $\mathrm{RH}$, and $14 \mathrm{~h}$ photophase).

\begin{tabular}{lllll}
\hline Stage & $N$ initial-final & Survival (\%) & $\begin{array}{l}\text { Duration } \\
\text { (days) }\end{array}$ & $\begin{array}{l}\text { Range } \\
\text { (days) }\end{array}$ \\
\hline Egg & $6485-6321$ & $97.5 \pm 0.31$ & $5.0 \pm 0.00$ & 5 \\
Larval & $300-291$ & $97.0 \pm 0.27$ & $21.3 \pm 1.63$ & $19-33$ \\
Prepupal & $291-271$ & $93.1 \pm 0.92$ & $3.1 \pm 0.78$ & $1-5$ \\
Pupal & $271-268$ & $98.9 \pm 0.12$ & $20.8 \pm 2.25$ & $17-34$ \\
Total & - & 87.1 & 50.2 & - \\
\hline
\end{tabular}

$90.3 \%$, and it was the lowest survival of all other stages. Most of the larvae (95.2\%) developed through six instars, and only 13 females (4.9\%) went through seven instars (Table 2). The total development time of the female larvae that went through six instars (24.9 days) was significantly longer than that of male larvae (23.7 days) (Table 2). The larval development time was the same in both sexes through the third instar. The development time of female larvae that went through seven instars (26.6 days) was significantly longer than that of female larvae that completed six instars (24.9) (Table 2). However, the larval development time was the same through the fourth instar, and females with an

Table 2 Development time (days) (mean \pm SE) of Spodoptera dolichos, during each instar, including the larvae of each sex which developed for six and seven instars, fed with an artificial diet, under controlled conditions $\left(25 \pm 1^{\circ} \mathrm{C}, 70 \pm 10 \% \mathrm{RH}\right.$, and $14 \mathrm{~h}$ photophase).

\begin{tabular}{|c|c|c|c|c|c|}
\hline \multirow[t]{2}{*}{ Larval instars } & \multicolumn{2}{|l|}{6 instars } & \multirow[t]{2}{*}{$A$} & \multirow{2}{*}{$\begin{array}{l}7 \text { instars } \\
\text { Females } \\
\text { (13) }\end{array}$} & \multirow[t]{2}{*}{ B } \\
\hline & $\begin{array}{l}\text { Females } \\
(124)\end{array}$ & $\begin{array}{l}\text { Males } \\
\text { (131) }\end{array}$ & & & \\
\hline I & $4.1 \pm 0.38$ & $4.1 \pm 0.46$ & ns & $4.0 \pm 0.00$ & ns \\
\hline II & $3.0 \pm 0.33$ & $3.0 \pm 0.37$ & ns & $3.0 \pm 0.00$ & ns \\
\hline III & $3.2 \pm 0.44$ & $3.1 \pm 0.53$ & ns & $3.0 \pm 0.00$ & ns \\
\hline IV & $3.5 \pm 0.53$ & $3.3 \pm 0.96$ & $*$ & $3.2 \pm 0.39$ & $\mathrm{~ns}$ \\
\hline V & $4.4 \pm 0.58$ & $4.0 \pm 0.83$ & $* *$ & $3.8 \pm 0.56$ & * \\
\hline VI & $3.5 \pm 0.92$ & $3.2 \pm 0.65$ & $* *$ & $2.8 \pm 0.56$ & * \\
\hline VII & - & - & & $3.5 \pm 0.66$ & \\
\hline Prepupae & $3.2 \pm 0.82$ & $3.0 \pm 0.76$ & ns & $3.2 \pm 0.60$ & ns \\
\hline Total $^{\mathrm{a}}$ & $24.9 \pm 1.52$ & $23.7 \pm 1.73$ & $* *$ & $26.6 \pm 1.50$ & $* *$ \\
\hline Pupae & $20.3 \pm 1.66$ & $21.1 \pm 2.50$ & $*$ & $21.5 \pm 3.55$ & ns \\
\hline Larvae+pupae & $45.2 \pm 2.14$ & $44.8 \pm 3.00$ & ns & $48.2 \pm 3.58$ & $*$ \\
\hline
\end{tabular}

A comparisons between means of females and males that underwent six instars using a Student $t$ test, considering different variances, at a significance level of 95\%; $B$ comparisons between means of females that underwent six instars and females that underwent seven instars, using a Student $t$ test, considering different variances, at a significance level of $95 \% ; n s p>0.05$.

${ }^{*} p<0.01 ;{ }^{* *} p<0.001$.

${ }^{a}$ Larval developmental time, including prepupae period. additional instar (seven instars) experienced a significantly faster larval development during both the fifth and sixth instars (Table 2). The prepupal development time did not differ between sexes or between larvae that went through six and seven instars (Table 2).

Concerning the size of the larvae, differences between sexes were only detected at the end of larval development in the sixth instar. Female larvae were larger than males at this stage (Table 3). In addition, females that went through six instars were significantly larger at the fifth and sixth instar stages than those that underwent seven instars (Table 3 ). However, the 13 larvae that had the additional seventh instar were larger in size (Table 3). The growth rate of larvae was faster for females undergoing through six instars than males with the same number of instars. Females that underwent seven instars had a slower growth rate (Table 3).

The sex ratio determined from 137 female and 131 male pupae was 0.51 , which does not differ significantly from a 1:1 ratio $\left(\chi^{2}=0.07 ; p=0.796\right)$. Pupal weight was variable within sex, and some pupae weighted approximately half that of others (Table 4). Considering larvae which went through six instars, female pupae were heavier than male. Female pupae from larvae that went through an additional seventh instar were the heaviest (Table 4).

Based on reports in the literature, larvae of $S$. dolichos can feed on 78 plant species. Our additional surveys identified 19 new host plants, which resulted in a list with 97 plant species belonging to 33 plant families (Table 4). The botanic families with the greatest number of plants consumed by $S$. dolichos larvae include Solanaceae (12), Asteraceae and Fabaceae (11), and Poaceae (6). The current list of plants includes cultivated and natural species, with an increase in the number of species commonly considered weeds, such as Vernonia tweedieana, Lolium multiflorum, Portulaca oleracea, and Datura stramonium (Online Supplementary Material - Table S1).

\section{Discussion}

Singh (1983) stated that a suitable artificial diet provides for at least $75 \%$ of insect survival. In the present study, immatures of $S$. dolichos were reared on an artificial diet under controlled conditions, with minimal interference, which resulted in a higher overall survival (87.1\%) (Table 1).

The relatively high egg viability and fecundity observed for S. dolichos (Table 1) are common attributes of representatives of Spodoptera. In addition, previous studies on Spodoptera reported that multiple mating is known to enhance the reproductive capacity, including fertility (Sadek 2001, Sadek \& Anderson 2007, Busato et al 2008, Montezano et al 2013b, 2014a). The incubation period of S. dolichos was constant and is longer than the one reported elsewhere at the same temperatures for other species of 
Table 3 Distance between frontal setae $(\mathrm{mm})$ (mean \pm SE) of Spodoptera dolichos larvae at each instar and respective growth ratios, including larvae which developed for six ( 15 females and 15 males) and seven instars ( 9 females), fed with an artificial diet, under controlled conditions $\left(25 \pm 1^{\circ} \mathrm{C}, 70 \pm\right.$ $10 \% \mathrm{RH}$, and $14 \mathrm{~h}$ photophase).

\begin{tabular}{|c|c|c|c|c|c|c|c|c|}
\hline \multirow[t]{2}{*}{ Instar } & \multicolumn{4}{|l|}{6 instars } & \multirow[t]{2}{*}{$A$} & \multicolumn{2}{|l|}{7 instars } & \multirow[t]{2}{*}{ B } \\
\hline & Females (15) & Growth ratio & Males (15) & Growth ratio & & Females (13) & Growth ratio & \\
\hline I & $0.1 \pm 0.01$ & - & $0.1 \pm 0.01$ & - & ns & $0.1 \pm 0.01$ & - & ns \\
\hline II & $0.2 \pm 0.03$ & 1.79 & $0.2 \pm 0.05$ & 1.87 & ns & $0.2 \pm 0.04$ & 1.74 & ns \\
\hline III & $0.4 \pm 0.09$ & 1.87 & $0.5 \pm 0.07$ & 1.87 & ns & $0.4 \pm 0.08$ & 1.76 & ns \\
\hline IV & $0.7 \pm 0.09$ & 1.66 & $0.7 \pm 0.11$ & 1.55 & ns & $0.7 \pm 0.14$ & 1.64 & ns \\
\hline V & $1.2 \pm 0.10$ & 1.57 & $1.1 \pm 0.08$ & 1.58 & ns & $1.0 \pm 0.10$ & 1.47 & $*$ \\
\hline $\mathrm{VI}$ & $1.9 \pm 0.17$ & 1.69 & $1.7 \pm 0.13$ & 1.53 & $* *$ & $1.5 \pm 0.13$ & 1.55 & $* *$ \\
\hline VII & - & - & - & - & & $2.1 \pm 0.33$ & 1.41 & - \\
\hline Mean & - & 1.72 & - & 1.68 & & - & 1.59 & - \\
\hline
\end{tabular}

A comparisons between means of females and males that underwent six instars using a Student $t$ test, considering different variances, at a significance level of 95\%; $B$ comparisons between means of females that underwent six instars and females that underwent seven instars, using a Student $t$ test, considering different variances, at a significance level of $95 \%$; $n s p>0.05$.

${ }^{*} p<0.01 ; * *<0.001$.

Spodoptera (Bavaresco et al 2002, Montezano et al 2013a, 2014b).

Overall larval survival was also high (Table 1) and similar to those observed under the same conditions for $S$. albula (Montezano et al 2013a) and S. eridania (Montezano et al $2014 b)$. The observation that most of the larvae (95.2\%) developed through six instars and only few $S$. dolichos females developed through seven instars (Table 2 ) indicates that diet and rearing conditions were satisfactory for their larval development in the laboratory. This is supported by earlier reports relating additional larval molts with unsuitable food plants or artificial diets (Parra et al 1977, Mattana \& Foerster 1988, Bavaresco et al 2004, Santos et al 2005).

However, besides food quantity and quality, several other factors could influence the number of larval instars (Esperk

Table 4 Pupal weight $(\mathrm{mg})$ (mean $\pm \mathrm{SE}$ ) of Spodoptera dolichos reared on artificial diet, including pupae whose larvae developed for six and seven instars (only females), under controlled conditions $\left(25 \pm 1^{\circ} \mathrm{C}, 70 \pm\right.$ $10 \% \mathrm{RH}$, and $14 \mathrm{~h}$ photophase).

\begin{tabular}{lllll}
\hline Larval instars & Gender & $N$ & Pupal weight (mg) & Range \\
\hline 6 & Female & 124 & $740.8 \pm 55.96$ & $568-1026$ \\
& Male & 131 & $700.8 \pm 63.21$ & $492-848$ \\
& Significance $^{\mathrm{a}}$ & & $*$ & - \\
7 & Female $^{1}$ & 13 & $893.8 \pm 121.63$ & $714-1109$ \\
& Significance $^{\mathrm{b}}$ & & $*$ & -
\end{tabular}

Comparison of means using a Student $t$ test, considering different variances, at a significance level of $95 \%$.

${ }^{*} p<0.001$.

${ }^{a}$ Comparisons between females/males with six larval instars.

${ }^{b}$ Comparisons between females/females with six and seven larval instars. et al 2007). In our study, only female $S$. dolichos developed an additional instar (Tables 2 and 3). This additional instar is probably due to the large body size of females (Table 4), and these results are consistent with observations in $S$. albula and S. eridania (Montezano et al 2013a, 2014b).

The longest developmental time for female larvae which went through seven instars (Table 2) was similar to that observed for S. albula (Montezano et al 2013a) and S. eridania (Montezano et al 2014b). It is also consistent with other studies of Spodoptera, where an increased larval period is associated with additional instars (e.g., Santos et al 2005, Cabezas et al 2013).

There was a significant difference in the overall developmental time between female and male $S$. dolichos larvae that underwent six instars (Table 2). The sex difference in the duration of the stages was significant from the fourth instar on. These results agree with the observations reported for S. albula and S. eridania (Montezano et al 2013a, 2014b). However, in the end, there was synchronization between male and female adult emergence of $S$. dolichos, since the development delay of females during the larval stage was compensated by a faster pupal development.

The mean width of the larval head capsule demonstrated that $S$. dolichos larvae are larger than those of $S$. albula (Montezano et al 2013a), Spodoptera cosmioides (Walker) (Zenker et al 2007), and S. eridania (Montezano et al 2014b) reared on a similar artificial diet and temperature. Even the comparison with the head capsule width of S. Iatifascia (Walker) reported by Levy \& Habeck (1976) demonstrated that $S$. dolichos have one of the largest larvae of the genus.

The growth rate decreased progressively until the last instar (Table 3). This pattern was similar for both sexes of 
larvae, and it is especially noticeable in female larvae that underwent seven instars. Similar decrease in growth rate was also observed for S. eridania (Mayer \& Babers 1944, Parra et al 1977, Valverde \& Sarmiento 1987, Mattana \& Foerster 1988, Montezano et al 2014b) and S. albula (Montezano et al 2013a).

Lower survival was observed during the prepupal period, along with a shorter period of development (Table 1). This period corresponds to the time when the larvae stop feeding and are preparing for the pupal stage, which is usually critical for holometabolous insects due to metamorphosis processes (Schneider 2009).

Pupal survivorship for both sexes of $S$. dolichos (Table 1) differed from those observed for S. albula (Montezano et al 2013a) and S. eridania (Santos et al 2005, Montezano et al 2014b).

The difference of weight between sexes during the pupal stage is relatively well documented in Spodoptera (e.g., Mattana \& Foerster 1988, Bavaresco et al 2004, Santos et al 2005, Montezano et al 2013a) and other Lepidoptera. The larger size of females undergoing seven instars (Table 4) is attributed to the additional instar (e.g., Esperk et al 2007, Nagoshi 2011, Montezano et al 2013a, Montezano et al 2014b).

The records of 94 plants from 33 families consumed by $S$. dolichos larvae (Online Supplementary Material Table S1) show the high degree of polyphagy of this species as earlier indicated (e.g., Crumb 1929, Silva et al 1968, Pogue 2002, Pastrana 2004). The large number of plants consumed by $S$. dolichos is comparable to $S$. albula (Montezano et al 2013a), S. eridania (Montezano et al 2014b), and Spodoptera frugiperda (JE Smith) (Casmuz et al 2010). However, each Spodoptera species was reported to consume more representatives of a certain botanic family: Fabaceae for S. albula (Montezano et al 2013a), Asteraceae for S. eridania (Montezano et al 2014b), Poaceae for S. frugiperda (Casmuz et al 2010), and Solanaceae for $S$. dolichos (Online Supplementary Material - Table S1).

In summary, the present study increases the biological knowledge of $S$. dolichos, an important Spodoptera species in the Americas. The larvae of this species are one of the largest in the Spodoptera genus, and it is expected to have a longer development time than other species. However, the investigation detailing the biological parameters of male and female immatures allowed documentation of differences between sexes during larval and the pupal stages.

Acknowledgments The authors thank Conselho Nacional de Desenvolvimento Científico e Tecnológico (CNPq) for granting the master's fellowship to the first author (557269/2010-5) and for financial assistance (482627/2010-7).
Electronic supplementary material The online version of this article (doi:10.1007/s13744-015-0333-2) contains supplementary material, which is available to authorized users.

\section{References}

Adlerz WC (1975) Natural control of three rindworm species and chemical control of the granulate cutworm, Feltia subterranea on watermelon. Proc Fla State Hortic 88:204-207

Angulo AO, Jana S (1982) La pupa de Spodoptera Guenée, 1852, en el norte de Chile (Lepidoptera: Noctudae). Agric Technol 42:347-349

Angulo AO, Olivares TS, Weigert GT (2008) Estados inmaduros de lepidópteros nóctuidos de importancia agrícola y forestal en Chile y claves para su identificación (Lepidoptera: Noctuidae), $3^{\text {at }}$ th edn. Universidad de Concepción, Concepción, p 154

Bavaresco A, Garcia MS, Grützmacher AD, Foresti J, Ringenberg R (2002) Biologia e exigências térmicas de Spodoptera cosmioides (Walk.) (Lepidoptera: Noctuidae). Neotrop Entomol 31:49-54

Bavaresco A, Garcia MS, Grützmacher AD, Ringenberg R, Foresti J (2004) Adequação de uma dieta artificial para a criação de Spodoptera cosmioides (Walk.) (Lepidoptera: Noctuidae) em Laboratório. Neotrop Entomol 33:155-161

Busato GR, Loeck AE, Garcia MS, Bernardi O, Zart M, Nunes AM, Zazycki LCF (2008) Compatibilidade reprodutiva entre biótipos "milho" e "arroz" de Spodoptera frugiperda (J.E. Smith) (Lepidoptera: Noctuidae). Rev Bras Agrociênc 14:273-278

Cabezas MF, Nava DE, Geissler LO, Melo M, Garcia MS, Krüger R (2013) Development and leaf consumption by Spodoptera cosmioides (Walker) (Lepidoptera: Noctuidae) reared on leaves of Agroenergy crops. Neotrop Entomol 42:588-594

Casmuz A, Juárez ML, Socías MG, Murúa MG, Prieto S, Medina S, Willink E, Gastaminza G (2010) Revisión de los hospederos del gusano cogollero del maíz, Spodoptera frugiperda (Lepidoptera: Noctuidae). Rev Soc Entomol Argent 69:209-231

Crumb SE (1929) Tobacco cutworms, vol 88. U.S.D.A. Tech Bull, Washington, 178p

Dias NS, Micheletti SMFB, Tourinho LL, Rodrigues VM (2009) Primeiro registro de ocorrência de Spodoptera spp. (Lepidoptera: Noctuidae) atacando crotalária no estado de Alagoas, Brasil. Caatinga 22:1-3

Esperk T, Tammaru T, Nylin S (2007) Intraspecific variability in number of larval instars in insects. J Econ Entomol 100:627-645

Ferguson DC, Hilburn DJ, Wright B (1991) The Lepidoptera of Bermuda: their food plants, biogeography, and means of dispersal. Mem Ent Soc Can 158:1-105

Greene GL, Leppla NC, Dickerson WA (1976) Velvetbean caterpillar: a rearing procedure and artificial medium. J Econ Entomol 69:487-488

Levy R, Habeck DH (1976) Descriptions of the larvae of Spodoptera sunia and S. latifascia with a key to the mature Spodoptera larvae of the Eastern United States (Lepidoptera: Noctuidae). Ann Entomol Soc Am 64:585-588

Matrangolo WJR, Cruz I, Della-Lucia TMC (1997) Insetos fitófagos presentes em estilos-estigma e espigas de milho e avaliação de dano. Pesq Agrop Brasileira 32:773-779

Mattana AL, Foerster LA (1988) Ciclo de vida de Spodoptera eridania (Cramer, 1782) (Lepidoptera: Noctuidae) em um novo hospedeiro, Bracatinga (Mimosa scabrella Bentham) (Leguminosae). An Soc Entomol Bras 17:173-183

Mayer EL, Babers FH (1944) Head-capsule measurements of Southern armyworm larvae (Prodenia eridania, Cramer). Ann Entomol Soc Am 37:214-220

Montezano DG, Specht A, Sosa-Gómez DR, Roque-Specht VF, Bortolin TM, Fronza E, Pezzi P, Luz PC, Barros NM (2013a) Immature stages of 
Spodoptera albula (Walker) (Lepidoptera: Noctuidae): developmental parameters and host plants. An Acad Bras Cienc 85:271-284

Montezano DG, Specht A, Sosa-Gómez DR, Roque-Specht VF, Barros NM (2013b) Biotic potential and reproductive parameters of Spodoptera eridania (Stoll) (Lepidoptera, Noctuidae) in the laboratory. Rev Bras Entomol 57:340-345

Montezano DG, Specht A, Sosa-Gómez DR, Roque-Specht VF, Bortolin TM, Fronza E, Pezzi P, Luz PC, Barros NM (2014a) Biotic potential, fertility and life table of Spodoptera albula (Walker) (Lepidoptera: Noctuidae), under controlled conditions. An Acad Bras Cienc 86: 723-732

Montezano DG, Specht A, Sosa-Gómez DR, Roque-Specht VF, Barros NM (2014b) Immature stages of the armyworm, Spodoptera eridania: developmental parameters and host plants. J Insect Sci 14(238):1-11

Moreira C (1929) Entomologia agrícola brasileira, 2nd edn. Ministério da Agricultura, Indústria e comércio, Rio de Janeiro, p 274

Nagoshi RN (2011) Artificial selection for developmental rates in fall armyworm (Lepidoptera: Noctuidae) and its implications on the design of feeding studies. Ann Entomol Soc Am 104:88-94

Parra JRP, Precetti AACM, Karsten P Jr (1977) Aspectos biológicos de Spodoptera eridania (Cramer, 1782) (Lepidoptera: Noctuidae) em soja e algodão. An Soc Entomol Bras 6:147-155

Pastrana JA (2004) Los Lepidópteros Argentinos: sus plantas hospedadoras y otros substratos alimenticios. Sociedad Entomológica Argentina, Buenos Aires, p 334

Pérez LRF, Martinez NB, Carrasco JV, Galvan ÓM, Luna SQ (2005) Comparación de técnicas de medida de cápsulas cefálicas para separar estádios larvales de Copitarsia incommida (Walquer) (Lepidoptera: Noctuidae). Acta Zool Mex Nueva Sér 21:109-113

Pogue GM (2002) A world revision of the genus Spodoptera Guenée (Lepidoptera: Noctuidae). Mem Am Entomol Soc 43:1-202

Sadek MM (2001) Polyandry in field-collected Spodoptera littoralis moths and laboratory assessment of the effects of male mating history. Entomol Exp Appl 98:165-172
Sadek MM, Anderson P (2007) Modulation of reproductive behavior of Spodoptera littoralis by host and non-host plant leaves. Basic Appl Ecol 8(2007):444-452

Santos KB, Meneguim AM, Neves PMOJ (2005) Biologia de Spodoptera eridania (Cramer) (Lepidoptera: Noctuidae) em diferentes hospedeiros. Neotrop Entomol 34:903-910

Schneider JC (2009) Principles and procedures for rearing high quality insects. Mississippi State University. 352p

Silva AGA, Gonçalves CR, Galvão DM, Gonçalves AJL, Gomes J, Silva MN, Simoni L (1968) Quarto catálogo dos insetos que vivem nas plantas do Brasil: seus parasitos e predadores. Ministério da Agricultura, Rio de Janeiro, p 622 (Parte II, $1^{\circ}$ tomo, Insetos, hospedeiros e inimigos naturais)

Singh P (1983) A general purpose laboratory diet mixture for rearing insects. Insect Sci Appl 4:357-362

Specht A, Corseuil E (2002) Diversidade dos noctuídeos (Lepidoptera, Noctuidae) em Salvador do Sul, Rio Grande do Sul, Brasil. Rev Bras Zool 19:281-298

Teixeira EP, Yokomizo NKS (1987) Ocorrência de Spodoptera dolichos (Fabr., 1794) (Lep., Noctuidae) em mudas de Pinus taeda L. e $P$. carabaea Morelet var. caribaea. Bol Técn Inst Florestal 41:337-341

Valverde CA, Sarmiento MJ (1987) Efecto de cuatro plantas hospedadoras en la biologia de Spodoptera eridania. Rev Per Entomol 29:55-60

Zagatti P, Lalanne-Cassou B, D'aubigny JD (2006) Catalogue of the Lepidoptera of the French Antilles. Institut National de la Recherche Agronomique. Available online at: http://www.inra.fr/papillon/ Accessed 14 ago 2013

Zenker MM, Specht A, Corseuil E (2007) Estágios imaturos de Spodoptera cosmioides (Walker) (Lepidoptera, Noctuidae). Rev Bras Zool 24:99-107

Zenker MM, Botton M, Teston JA, Specht A (2010) Noctuidae moths occurring in grape orchards in Serra Gaúcha, Brazil and their relation to fruit-piercing. Rev Bras Entomol 54:288-297 